\title{
Role and management of in-channel wood in relation to flood events in Southern Andes basins
}

L. Mao ${ }^{1}$, F. Comiti ${ }^{1}$, A. Andreoli ${ }^{2}$, L. Picco ${ }^{1}$, M. A. Lenzi ${ }^{1}$,

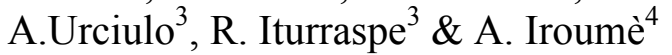

${ }^{1}$ Department of Land and Agroforest Environment,

University of Padova, Italy

${ }^{2}$ Universidad de Concepcion, Chile

${ }^{3}$ Subsecretaría de Recursos Naturales de Tierra del Fuego, Ushuaia, Argentina

${ }^{4}$ Instituto de Manejo Forestal, Universidad Austral de Chile, Chile

\begin{abstract}
This paper analyses the connection among wood dynamics, channel morphology and flood risk in mountain basins of the Southern Chilean Andes and of the Argentinean Tierra del Fuego. Guidelines for the management of in-channel wood and of the riparian buffer strip are suggested, along with considerations about possible input from landslides and debris flows. A selection of low-impact check dams specifically designed for the retention of floating LW elements is finally provided.
\end{abstract}

Keywords: woody debris, mountain rivers, flood risk, control works.

\section{Introduction}

Large wood (LW) in mountain streams plays - especially when organized in jams - relevant geomorphic and biological roles which enhance the ecological status of natural channels by increasing morphological diversity and complexity [6]. LW accumulations strongly affect also flow hydraulics and transport/storage of sediments within the channel system, thus conditioning channel dimensions [12] and typology and distribution of bedforms [11]. These beneficial effects persist from low to high flows, and throughout the entire channel network. 
On the other hand, LW elements may be a source of risk during intense flood periods and in localised areas only. Wood may increase flood risk by a variety of processes, such as flow and sediment surges following collapse of temporary wood dams, inclusion and strengthening of debris flows, clogging on bridge piers and other structures, local bed scour and local bank erosion. Of course, the risks associated to in-channel wood are strongly dependent on the degree of human presence within a catchment (frequency and type of road crossings, proximity and density of humans adjacent to the channels). Therefore, it is evident how a balanced, integrated management of in-channel wood and of the adjacent input areas is absolutely needed. Furthermore, an ecologically-oriented management approach is especially required for mountain basins still presenting a high degree of naturalness such as in the Southern Andes, which represent an ideal location for studying $\mathrm{LW}$ in mountain channels draining old-growth forested basins.

\section{Wood storage in Southern Andes streams}

Recently, field investigations shed light on storage and effects of large wood in mountain streams of Southern Andes [1, 5, 8]. Three study basins were examined (fig. 1), one located in Tierra del Fuego near the city of Ushuaia (Buena Esperanza), and two in the Araucania region of Chile (Tres Arroyos and Rio Toro) that differ with regard to fires disturbance history. Table 1 provides a summary of the main characteristics of the basins.

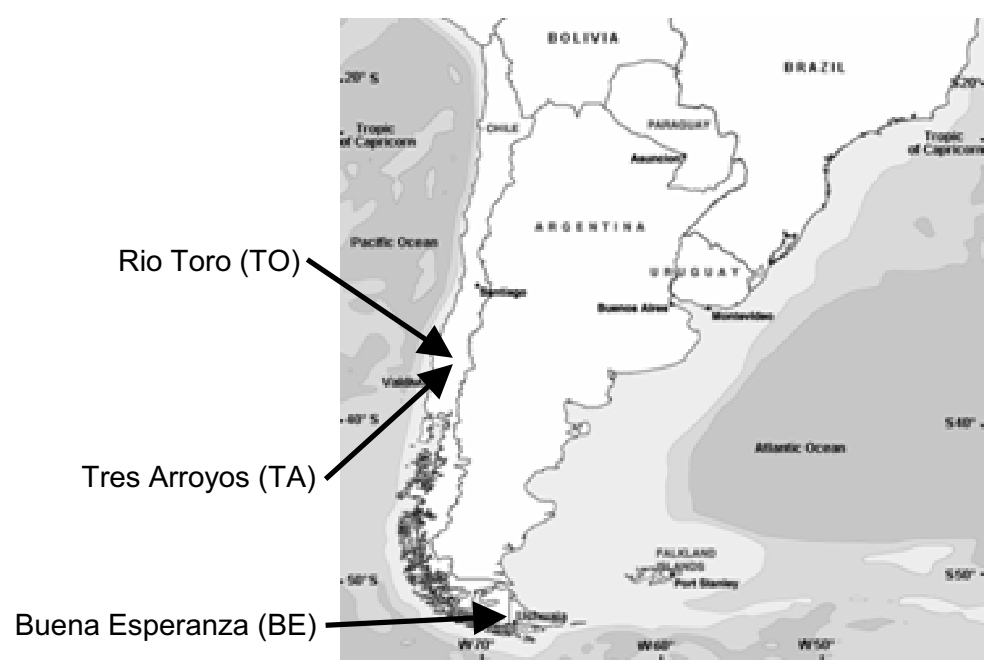

Figure 1: $\quad$ Location of the investigated basins. 
Table 1: Basins characteristics.

\begin{tabular}{|l|c|c|c|}
\hline \multicolumn{1}{|c|}{$\begin{array}{c}\text { Basin } \\
\text { characteristics }\end{array}$} & $\begin{array}{c}\text { Tres Arroyos } \\
\text { (TA) }\end{array}$ & $\begin{array}{c}\text { Toro } \\
\text { (TO) }\end{array}$ & $\begin{array}{c}\text { Buena Esperanza } \\
\text { (BE) }\end{array}$ \\
\hline Basin Area $\left(\mathrm{km}^{2}\right)$ & 9.1 & 11.1 & 12.9 \\
\hline $\begin{array}{l}\text { Mean basin slope } \\
(\%)\end{array}$ & 43 & 20 & 23 \\
\hline Climate & $\begin{array}{c}\text { Temperate warm } \\
\text { humid }\end{array}$ & $\begin{array}{c}\text { Temperate warm } \\
\text { humid }\end{array}$ & $\begin{array}{c}\text { Temperate cold } \\
\text { humid }\end{array}$ \\
\hline Hydrological regime & pluvial/nival & pluvial/nival & glacionival \\
\hline Annual Precipitation & 2217 & 2480 & $530 / 1300$ \\
\hline Geology & $\begin{array}{c}\text { Volcanic / } \\
\text { pyroclastic }\end{array}$ & $\begin{array}{c}\text { Volcanic / } \\
\text { pyroclastic }\end{array}$ & $\begin{array}{c}\text { Sedimentary/ } \\
\text { Metamorphic }\end{array}$ \\
\hline Forest disturbances & Wildfire (1920's) & Wildfire (2002) & Wind blowdowns (?) \\
\hline $\begin{array}{l}\text { Average channel } \\
\text { slope (m/m) }\end{array}$ & 0.08 & 0.05 & 0.065 \\
\hline $\begin{array}{l}\text { Average channel } \\
\text { width (m) }\end{array}$ & 7.7 & 11.9 & 6.3 \\
\hline
\end{tabular}

In-channel wood quantity in old-growth forested mountain basins of Southern Andes can vary considerably both between and within channels. LW storage in the Tres Arroyos (around $700 \mathrm{~m}^{3} \mathrm{ha}^{-1}$ in the active channel, or $556 \mathrm{~m}^{3} \mathrm{~km}^{-1}$ based on channel length) is extremely abundant. Comparably high values have been reported only for old-growth redwood forests in the Pacific Northwest, where average wood storage of up to $1,000 \mathrm{~m}^{3} \mathrm{ha}^{-1}$ were recorded [7]. The relatively low LW volume stored in the Buena Esperanza $\left(120 \mathrm{~m}^{3} \mathrm{ha}^{-1} ; 76 \mathrm{~m}^{3} \mathrm{~km}^{-1}\right)$ is determined by small $\log$ diameters, in turn deriving from the extremely slow growth of nothofagus in the Tierra del Fuego, notwithstanding the extremely high abundance of wood pieces [5, 8]. The Rio Toro is instead characterized by a relatively low supply of large wood that overall makes its LW storage comparable to the Buena Esperanza $\left(117 \mathrm{~m}^{3} \mathrm{ha}^{-1} ; 144 \mathrm{~m}^{3} \mathrm{~km}^{-1}\right)$.

The high LW storage in the Tres Arroyos can be partly attributed to the small fraction of wood pieces moved by "ordinary" floods. As a term of comparison, in the Mack Creek, a third-order stream that flows through a old-growing coniferous forest, the average wood storage is very high $\left(812 \mathrm{~m}^{3} \mathrm{ha}^{-1} ;[6]\right)$ because of the small fraction of LW elements moved by ordinary events $(<1 \%$; [6]. In the Tres Arroyos, similarly low percentage of wood pieces $(2.5-4 \%)$ is mobilized each year by ordinary floods, while a greater fraction of logs are transported by flow in the Buena Esperanza (10\%) probably due, once again, to the smaller dimensions of the logs, so easier to be moved.

The strong longitudinal variation of LW quantity in the Tres Arroyos and in the Buena Esperanza, as well as its link to "external" factors (occasional large trees fallen into the channel, debris flows confluences and landslides) rather than to channel properties $[5,8]$, reflects what observed in $2^{\text {nd }}-4^{\text {th }}$ order channels of the Italian Dolomites [4]. 
Interestingly, differences may be substantial even in adjacent basins, and less pronounced between different climates and forest type (i.e. latitudes). Latitude surely acts on tree growth (i.e. wood diameter) and on natural forest disturbance processes (i.e. wildfire vs. windblown moving southward), but notwithstanding different log size and log number the net effect on channel morphology is apparently very similar. In the sub-Antarctic climate of Tierra del Fuego, wood rarely reach large dimensions [5, 8] but its abundant supply by wind-caused mortality [14] make streams prone to be locally grade-controlled by valley jams (Fig. 2(a)) and log steps (Fig. 2(b)) composed of floated debris trapped by occasional fallen trees.
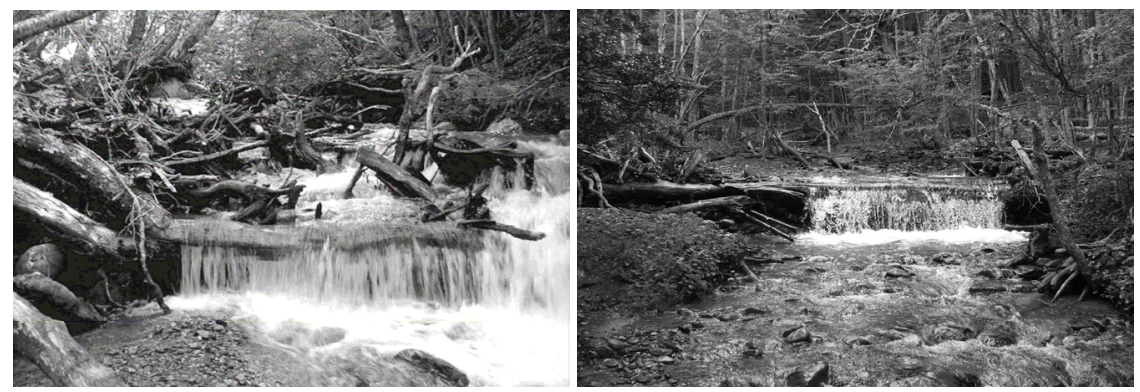

Figure 2: Valley jam (a) and $\log$ step (b) in the Buena Esperanza main channel.

In the warmer climate of the Araucania, fires command forest regeneration and thus probably wood supply to channels. However, in-channel wood loading does not respond immediately to wildfire but a certain lag time of several decades exists [2, 16]. This may explain why wood volumes are so different between the Rio Toro - where almost all the basin forests burned in 2002 - and the Tres Arroyos, which is now heavily dissected as a consequence of fires occurred almost a century ago. Of course, basin geology and topography plays a fundamental role in delivering burned dead wood from the hillslope to the main channel. In the Rio Toro the burned trees are still standing (fig. 3(a)), and no landslides have taken place yet in the basin, possibly as a consequence of the smaller basin slope (fig. 3).

In contrast, in the Tres Arroyos, the destruction of the forest cover caused severe slope instability (fig. 4) that in turn resulted in debris flow phenomena able to transport many huge pieces of wood into the stream, prompting the formation of massive valley jams. An enormous accumulation of LW (gross geometrical volume $\sim 600 \mathrm{~m}^{3}$ ), formed by $100-150$ wood pieces $0.5 \mathrm{~m}$ in diameter and 4-5 $\mathrm{m}$ long on average, lies at the confluence of this debris flow channel with the main Tres Arroyos channel. Figure 5 shows two images of the channel depicting the stream upstream of the confluence through the old-growth stands (a), and the stream downstream of the valley jam (b). The location of the valley jams is clearly linked to external forcings such as landslides, actively eroded banks and the confluences with debris flow channels, which provide the 


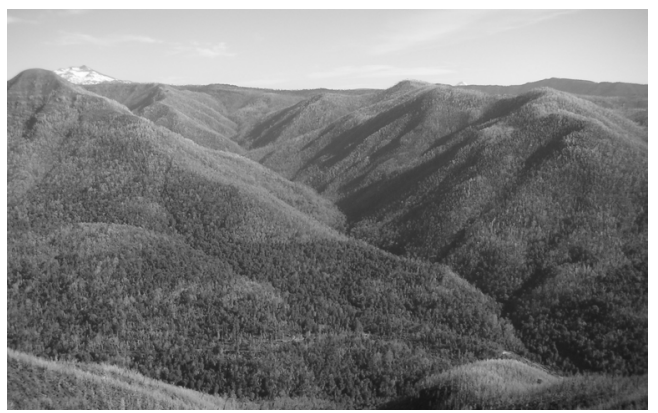

Figure 3: View of the Rio Toro basin.

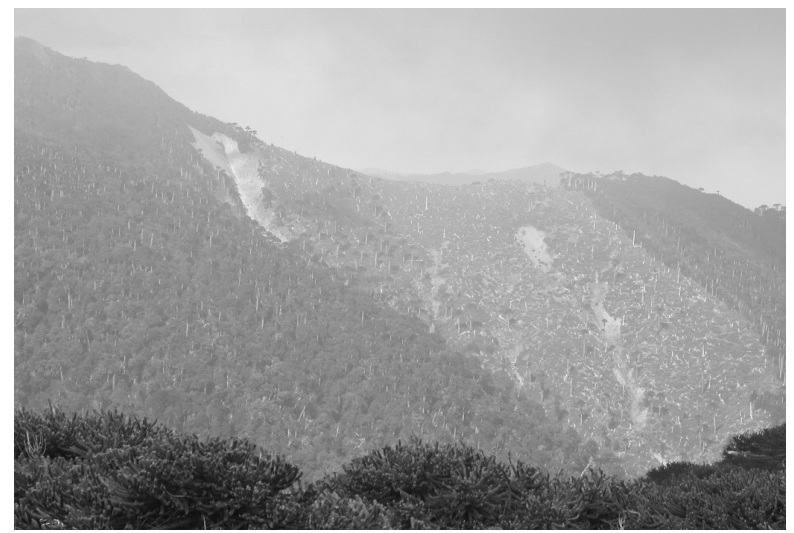

Figure 4: Landslides and minor debris flow on the hillslopes of the Tres Arroyos.

main channel with large, stable wood pieces able to build up a large transversal jam structure by trapping smaller wood pieces [1].

\section{Wood management options}

The previous section has illustrated how in-channel woody debris represents a fundamental component of the upland channel networks morphology and processes in the Southern Andes. In contrast to European basins, much of the original geomorphological and ecological richness deriving from an abundant presence of wood in the stream network can still be found in many parts of the temperate Andes. At the same time, the human presence is there rapidly encroaching pristine or semi-pristine basins, thus increasing flood risk by building infrastructures and residential structures within fluvial corridors (i.e. active floodplains and channels) and on alluvial fans, parts of the landscape which are naturally subject to potentially dangerous transport of sediment and wood during major flood events (i.e., recurrence interval $>20-30 \mathrm{yr}$ ). 

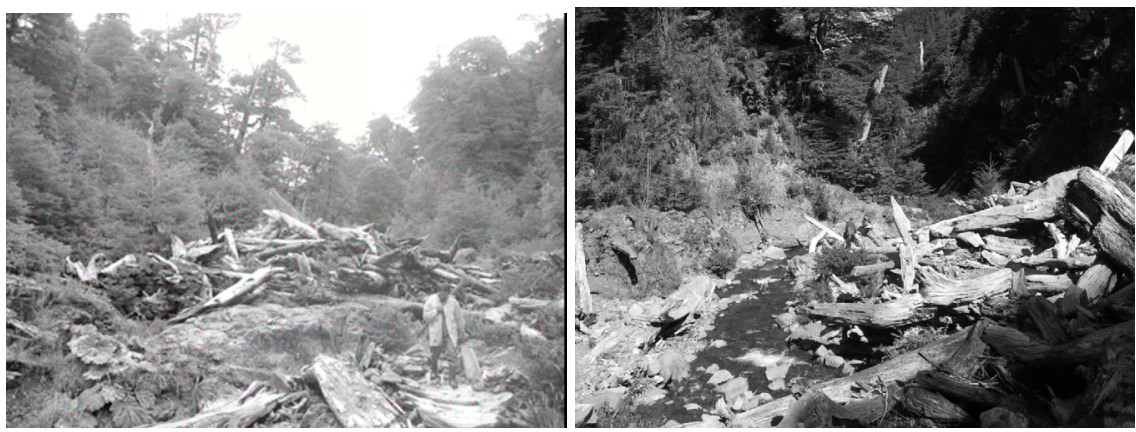

Figure 5: Downstream (a) and upstream (b) view of a big valley jam in the Tres Arroyos channel.

Therefore, the first management option against flood risk - not only due to floating wood - is avoid building any valuable structure in flood-prone areas, i.e. the adoption of a careful land use planning. However, if something is already located in the fluvial corridor because of ill-advised decisions of the past, priority should be given to assess whether its removal (i.e. relocation) is feasible, because this option is often the most sustainable in the long run. For minor infrastructure, some solutions as debris sweepers at bridge piers and racks at culverts [3] might be sufficient. A change in building typology could also be a good strategy (e.g., a suspension bridge instead of having piers).

In the case buildings and/or infrastructures of major relevance cannot be relocated and wood is recognized to represent a significant hazard during major floods (20-100 yr return interval), the adoption of structural countermeasures is needed, after an evaluation of where and how much wood will enter the network, as well as where critical cross-sections for obstructions are situated. Because these control works can be expensive, their construction must be justified by a cost-benefit analysis. Next section will provide a brief overview on the principal control works for the wood entrapment and on the parameters to be considered in the choice of the most appropriate type.

Removal of wood and of riparian trees from the channel, typically viewed as "ordinary maintenance" of the entire stream network, should be adopted only locally where it is clear that a dangerous jam is being formed at a critical crosssection. Furthermore, such operation is an expensive, mostly useless activity, with negative effects on stream morphology, stability and ecological status.

These considerations are organised as a flow chart in Figure 6, developed for basins $<200-300 \mathrm{~km}^{2}$.

\section{Control works for the retention of driftwood}

In those cases where the removal/relocation of vulnerable human elements is not socially or technically feasible, the installation of localized control works is often the most recommendable alternative (Fig. 6). In-channel control works for 


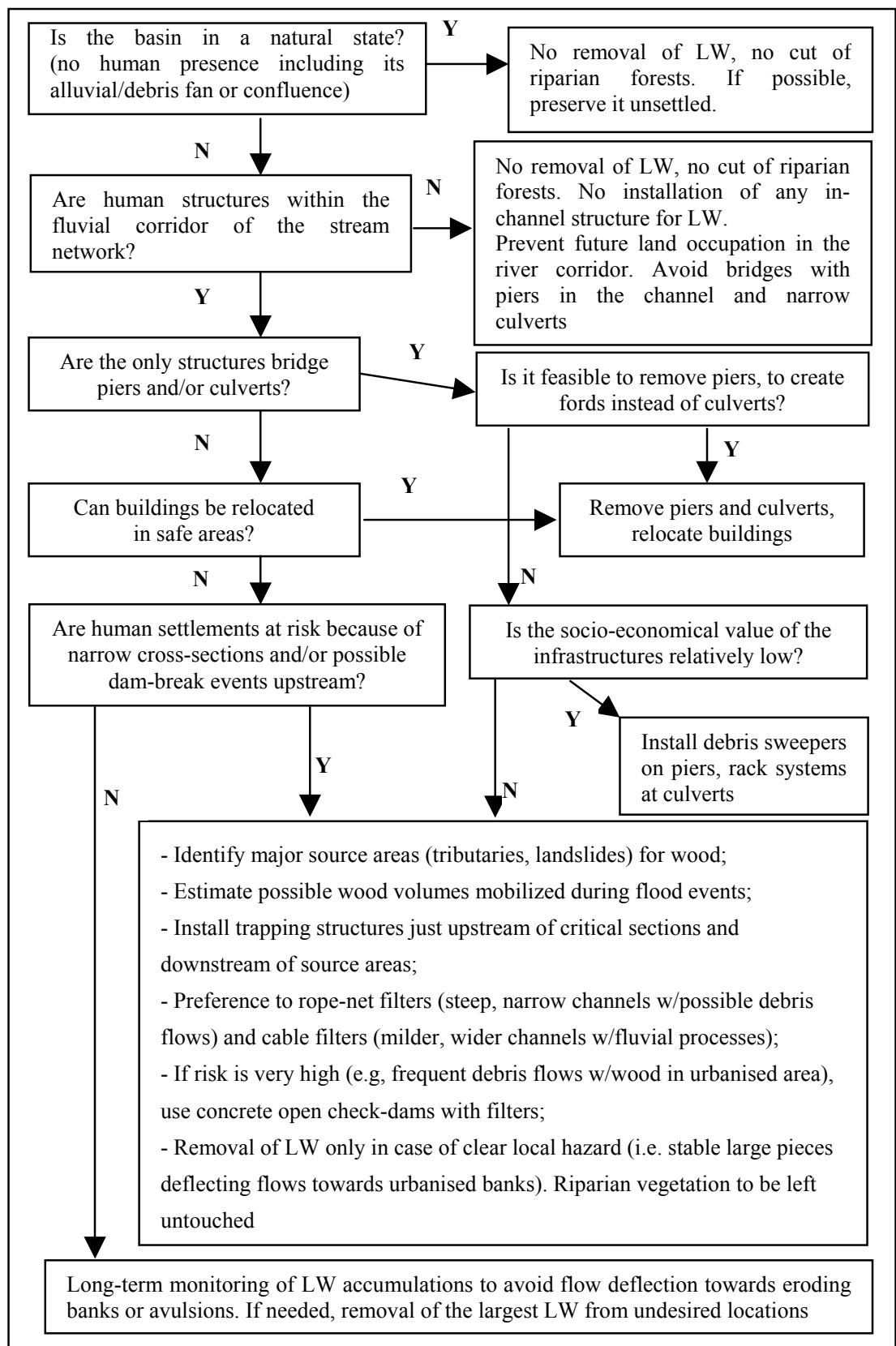

Figure 6: Large wood management options.

retention of wood transported during major floods have been developed in the densely populated European and Japanese Alps. The choice of the most 
appropriate retention structure depends on channel width and on the amount of large wood potentially transportable by flood events. As previously pointed out, this second variable is highly variable between basins, but can be evaluated thought field surveys [5] or interpretation of aerial photos [13]. Airborne multispectral imagery [9] has been also tested, but with poor success. In mountain basins of the Southern Andes, filter concrete check dams, rope net barriers and cable filter dams may be selected depending on the basin/channel characteristics.

Filter check dams are commonly built in the European Alps to "break" debris flows and to store the coarser fraction of the transported sediments. From their modification with inclined buttresses and grids, wood-oriented check dams have been developed to trap floating logs in mountain rivers (Fig. 7(a)). Rope net barriers (Fig. 7(b)) are designed for gravel and wood entrapment in small streams, and have been investigated [15] by physical modelling and in the field. For their design, the main required parameters are the height of the net (which is based on the gradient of the torrent), the potential amount of wood to be entrapped, and the design discharge [15]. Cable filter dams (Fig. 7(c)) are composed of harmonic steel cables $(\varnothing \sim 10 \mathrm{~cm})$ fixed on the river banks by tiebeams and fixed at the river centreline on a buttress to reduce the cables span. This configuration also forces the trapped wood to accumulate towards the river banks where it can be removed. Two of these structures have been recently built along the Sarca River (Italian Alps, Trento) and have demonstrated to efficiently exert a filtering action even during a severe flood with intense wood transport $[10]$.
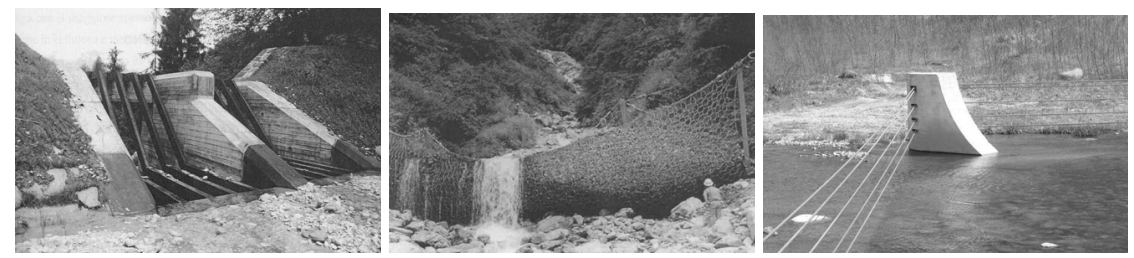

Figure 7: Wood retention control works: a filter concrete check dam (a), a rope net barrier (b), and a cable filter dam (c).

\section{Conclusions}

Dead wood pieces, especially when organized in jams, play an important geomorphic role in streams because of the effects on flow hydraulics, pool formation and sediments storage and ecological diversity and complexity. The three analysed Southern Andes basins show that very large variations in the volume of LW per unit of streambed area occur even within single streams, and that massive inputs may result from slope instabilities adjacent to the channels. Major differences in wood abundance exist due to the basins' disturbance history, and massive wood volumes (i.e., $>1000 \mathrm{~m}^{3} \mathrm{ha}^{-1}$ ) can be reached in basins disturbed by fires followed by mass movements and debris flows. In-channel 
wood in Andean basins is a precious resource for stream stability and ecological status which should be preserved. However, hazards linked to in-channel wood might likely depend on local, massive inputs of whole portions of forested slopes adjacent to the channels due to mass wasting processes. Prevention and monitoring of hillslope instabilities thus becomes a critical aspect of flood risk mitigation also in relation with wood transport, and is more effective than frequent, anti-ecological cuts of the riparian vegetation. Only in case of high risks for human settlements and infrastructures, wood-trapping structures might be worth to be installed upstream of sensitive locations.

\section{References}

[1] Andreoli A., Comiti F. \& Lenzi M.A., Characteristic, distribution and geomorphic role of large woody debris in a mountain stream of the Chilean Andes. Earth Surface Processes and Landforms, 33(11), pp. 1675-1692, 2007.

[2] Benda L., Miller D., Sias J., Martin D., Bilby R., Veldhuisen C., Dunne T., Wood recruitment processes and wood budgeting. In The Ecology and Management of Wood in World Rivers, ed. S.V. Gregory, K.L. Boyer, A.M. Gurnell, American Fisheries Society: Bethesda, MD, pp. 49-73, 2003.

[3] Bradley J.B., Richard D.L., Bahner C.D., Debris control structure, Evaluation and countermeasures. Hydraulic Engineering Circular 9. U.S. D.T., Federal Highway Administration, pp. 179, 2005.

[4] Comiti F., Andreoli A., Lenzi M.A. \& Mao L., Spatial density and characteristics of woody debris in five mountain rivers of the Dolomites (Italian Alps). Geomorphology, 78, pp. 44-63, 2006.

[5] Comiti F., Andreoli A., Mao L. \& Lenzi M.A., Wood storage in three mountain streams of the Southern Andes and its hydro-morphological effects. Earth Surface Processes and Landforms, 33(2), pp. 244-262, 2008.

[6] Gurnell, A.M., Piegay, H., Gregory, S.V. \& Swanson F.J., Large wood and fluvial processes. Freshwater Biology, 47, pp. 601-619, 2002.

[7] Gurnell A.M., Wood storage and mobility. In The Ecology and Management of Wood in World Rivers, ed. S.V. Gregory, K.L. Boyer, A.M. Gurnell, American Fisheries Society: Bethesda, MD, pp. 75-91, 2003.

[8] Mao L., Andreoli A., Comiti F., Lenzi M.A., Geomorphic effects of large wood jams on a sub-antarctic mountain stream. River Research and Applications, in press.

[9] Marcus, A.W., Marston, R.A., Colvard Jr, C.R. \& Gray, R.D., Mapping the spatial and temporal distributions of woody debris in streams of the Greater Yellowstone Ecosystem, USA. Geomorphology, 44, pp. 323-335, 2002.

[10] Mazzalai P., Cristofori V., Pecorari E., Lenzi M.A., Briglia a fune sul fiume sarca per la trattenuta di detriti legnosi. Quaderni di Idronomia Montana, 26, 425-438, 2006.

[11] Montgomery, D.R., Buffington, J.M., Smith, R.D., Schmidt, K.M. \& Pess G., Pool spacing in forest channels. Water Resources Research, 31(4), pp. 1097-1105, 1995. 
[12] Nakamura, F. \& Swanson, F.J., Effects of coarse woody debris on morphology and sediment storage of a mountain stream system in western Oregon. Earth Surface Processes and Landforms, 18, pp. 43-61, 1993.

[13] Pecorari E., Comiti F., Rigon E., Picco L. \& Lenzi M.A., Caratterizzazione e quantificazione del legname in alveo in corsi d'acqua di grandi dimensioni: risultati preliminari sul fiume Piave, Italia. Quaderni di Idronomia Montana, 27/1, 477-488, 2007.

[14] Rebertus, A.J., Kitzberger, T., Veblen, T.T. \& Roovers, L.M., Blowdown history and landscape patterns in the Andes of Tierra del Fuego, Argentina. Ecology, 78(3), pp. 678-692, 1997.

[15] Rimbock, A., Design of rope net barriers for woody debris entrapment. Introduction of a design concept. Proc. of the $10^{\text {th }}$ Interpraevent Symposium, Riva del Garda, Italy, pp. 265-276, 2004.

[16] Zelt, R.B. \& Wohl, E.E., Channel and woody debris characteristics in adjacent burned and unburned watersheds a decade after wildfire, Park County, Wyoming. Geomorphology, 57, pp. 217-233, 2004. 